\title{
An empirical analysis of alternative ways that terrorist groups end
}

\author{
Khusrav Gaibulloev • Todd Sandler
}

Received: 12 June 2013 / Accepted: 23 October 2013 / Published online: 8 November 2013

(C) The Author(s) 2013. This article is published with open access at Springerlink.com

\begin{abstract}
This paper implements discrete-time survival models to ascertain the determinants behind specific endings for terrorist groups during 1970-2007. Based on multinomial logit regressions, we estimate the hazard probabilities associated with three endings for terrorist groups: splintering from internal factors, being defeated by force, and joining the political process or achieving victory. We find that different covariates differentially impact each of these endings. In a second exercise, we split our sample of 586 terrorist groups into those that started before and after the beginning of 1990. In so doing, we find that survival factors differ between the two cohorts of groups. For both exercises, the determinants of survival comprise terrorist groups' goals, their tactics and size, and base-country characteristics. Robustness tests conclude the paper.
\end{abstract}

Keywords Terrorist group survival · Multinomial logit analysis · Panel analysis · Alternative ending of terrorist groups

JEL Classification D74 $\cdot$ C41 $\cdot$ H56

\section{Introduction}

An understanding of why terrorist groups end their operations is absolutely essential for effective counterterrorism policy, because this knowledge can enlighten policymakers as to which groups are vulnerable from within, and which can be defeated through police or military actions. If, for example, a terrorist group possesses the indicators of a group that

K. Gaibulloev

Department of Economics, American University of Sharjah, Sharjah, United Arab Emirates

e-mail:kgaibulloev@aus.edu

T. Sandler $(\bowtie)$

School of Economic, Political \& Policy Sciences, University of Texas at Dallas, 800 W. Campbell

Road, Richardson, TX 75080, USA

e-mail: tsandler@utdallas.edu 
will disintegrate internally, then the government is better advised to direct its limited counterterrorism resources to more resilient groups (Jones and Libicki 2008). Terrorist groups that are vulnerable from within can splinter from internal dissension among its members, competition with rival groups, reduced popular support, or limited resource supplies. The accumulation of nearly 40 years of terrorist event data, which often identify the perpetrating terrorist group, permits researchers to track empirically the campaigns of terrorist groups. Based on RAND (2012) terrorist event data for 1970-2006 and other information, Jones and Libicki (2008) distinguished active terrorist groups from those that concluded operations for one of the following reasons: defeat by military or police, splintering from within, joining the political process, or achieving one or more goals (i.e., victory). When observations on terrorist groups' campaigns are combined with data on these groups' characteristics (e.g., sizes, ideologies, and goals), tactics, and base-country features, we can ascertain the determinants behind various endings for terrorist groups.

Most previous studies of terrorist groups' demises have not investigated the determinants of specific types of endings (e.g., Blomberg et al. 2010; Gaibulloev and Sandler 2013; Phillips 2013); rather, these earlier studies examined the factors behind terrorist groups stopping operations for any reason. This presumes that the same factors are behind the various endings of terrorist groups, which is clearly not true since the determinants of military annihilation are likely different than those behind a group joining the political process. In a pioneering study, Blomberg et al. (2010) applied survival analysis to identify some factors that resulted in a three-year hiatus in attacks by terrorist groups. A follow-up study by Blomberg et al. (2011) identified factors behind terrorist groups' failure, based on the conclusion of terrorist operations, not just a hiatus in attacks. This is a desirable extension because terrorist groups may engage in a cease-fire or else suspend operations for one or more years. Subsequently, Gaibulloev and Sandler (2013) relied on RAND event data to study factors behind terrorist groups' failures for $60 \%$ more terrorist groups than analyzed in the Blomberg et al. (2011) article. These three studies did not, however, identify the specific determinants of the various types of endings for terrorist groups. Cronin (2006), however, analyzed some interesting case studies for specific terrorist groups' endings, but did not present a survival analysis.

Carter (2012) is the first article to apply a competing-risk analysis to identify some determinants that resulted in either internal dissolution or external defeat for terrorist groups. ${ }^{1}$ The focus of his survival analysis was the influence of state sponsorship. Carter (2012) uncovered some evidence that state sponsorship hastened groups' failures when this sponsorship took the form of providing a safe haven. Our paper also investigates why terrorist groups end in alternative ways, but without a focus on state sponsorship. Unlike Carter (2012), we divide groups' internal dissolution into two competing risks - splintering and joining the political process - since we view these risks as depending on vastly different considerations. Splintering indicates within group failure to pursue a common goal, while joining the political process suggests group unity in seeking goals by legitimate means. Additionally, we focus on base-country, rather than target-country, characteristics, because we believe that the survival of terrorist groups and the way in which they end is more geared to where the groups take refuge, draw their support, and deploy their defenses than where they

\footnotetext{
${ }^{1}$ Daxecker and Hess (2013) also investigated the determinants of alternative endings of terrorist groups. Unlike our current study, Daxecker and Hess (2013) focused on how government repression influenced terrorist groups' demises under alternative regimes-democracy and authoritarian. Their study excluded group splintering and covered a shorter period than our study. Many other differences distinguish these two studies.
} 
dispatch their operatives to attack (Basuchoudhary and Shughart 2010). In contrast to previous competing risk studies, the current study assembles a richer set of independent variables that account for the terrorist groups' competitive environment, their tactics (e.g., intensity and diversity of attacks), and environmental factors (e.g., the presence of multiple bases and geographical considerations).

The primary purpose of our paper is the implementation of discrete-time duration models to estimate the underlying determinants of specific kinds of terrorist groups' endings. ${ }^{2}$ During each year, an active terrorist group is at risk of alternative endings, i.e., being defeated by force, splintering from within, or joining the political process. We combine terrorist groups that achieve victory with those that enter the political process, since both types of terrorist groups have joined the established political order. Using multinomial logit regressions, we estimate the hazard probability for a sample of 586 terrorist groups that may have concluded operations in one of these three ways. Terrorist groups that do not succumb to one of these three risks remain active throughout the 1970-2007 sample period. A secondary purpose of our study is to ascertain the determinants of the demises of terrorist groups that formed during two subperiods-1970-1989 and 1990-2007. This division of time allows us to ascertain whether overall risk factors for terrorist groups differ between the earlier period when leftist and nationalist/separatist terrorists dominated and the later period when religious fundamentalist terrorists dominated (Hoffman 2006; Rapoport 2004).

Our analysis is rich in findings. Larger memberships make terrorist groups resilient to any of the alternative ways of ending, but have the greatest marginal impact on internal splintering. Relative to religious fundamentalists, terrorist groups formed around three other ideologies—nationalist/separatist (henceforth, nationalist), left wing, and right wing — are more likely to join the political process or achieve victory. This is especially true of nationalist terrorist groups, which supports the findings of Brathwaite (2013), who examined a much smaller number of terrorist groups. Terrorist groups with broadly defined goals, such as empire, regime change, or social revolution, are less inclined to join the political process. $^{3}$ This is also true of terrorist groups seeking territorial change. In addition, terrorist groups with multiple home bases are less apt to end by force or splintering. Large basecountry population reduces the risk that terrorist groups will splinter or join the political process. Base-country elevation and jungles limit terrorist groups' risk of a military defeat, presumably because the terrorist groups can better hide (also see Abadie 2006).

In the second exercise, we find numerous differences between the causes of demise for terrorist groups that formed before and after 1990. Relative to religious fundamentalist terrorist groups, the three other kinds of terrorist groups are more likely to end when the groups started before 1990. Terrorist groups seeking empire, regime change, or social revolution are less apt to end if they formed before 1990. Moreover, terrorist groups that want territorial change are more resilient to failure. For terrorist groups that began before 1990, we find that more terrorist attacks per million persons make the group more prone to failure. More attack

\footnotetext{
${ }^{2}$ With the availability of data on terrorist groups' campaigns, many recent articles study terrorist groups' activities. For example, Kilberg (2012) examined factors that affected a terrorist group's choice of organizational structure in its effort to balance effectiveness and security. Brathwaite (2013) demonstrated that terrorist organizations were more apt to adopt electoral strategies when they sought nationalist territorial goals.

${ }^{3}$ In a study of terrorist group emergence, Aksoy and Carter (2014) showed that terrorist groups with these "anti-system" goals are less likely to emerge in democracies. Their findings about how groups' goals determine where terrorist groups emerge are consistent with our findings that terrorist groups with systemconsistent goals are more apt to join the political process.
} 
diversity displayed by the terrorist group is more conducive to survival before 1990, but not after the beginning of 1990. Terrorist group competition within the base country increases survival prospects for terrorist groups forming after, but not before, 1990. Other findings are highlighted in the results section (Sect. 5).

\section{Preliminaries}

Terrorism is the premeditated use or threat to use violence by individuals or subnational groups to obtain a political or social objective through the intimidation of a large audience beyond that of the immediate victims (Enders and Sandler 2012). The two hallmarks of terrorism are its violence and political/social objectives. Violent actions in the absence of these goals merely are criminal acts for extortion or sociopathic reasons. Political or social goals may involve making territorial demands, altering public policy, maintaining the status quo, growing an empire, encouraging regime change, or fostering social revolution (Jones and Libicki 2008). Terrorist groups support the status quo if they oppose policy changes being pushed by the government or other political groups. Smaller terrorist groups make more modest demands such as policy change, while larger terrorist groups seek grander demands such as empire, regime change, or social revolutions (Jones and Libicki 2008). In some instances, terrorist groups pursue regionwide regime change (i.e., empire)—e.g., Jemaah Islamiyah wants a pan-regional Islamic state. ${ }^{4}$ Our terrorism definition concurs with that of RAND (2012) by identifying the perpetrator as individuals or subnational groups so as to rule out state terror, wherein a government intimidates its own people. However, our terrorism definition does not rule out state sponsorship in which a government aids the terrorist group with resources, intelligence, safe haven, or other forms of support. Terrorist groups want the intimidated audience to pressure the government to concede in order to reduce anxiety levels (Gould and Klor 2010). The audience is particularly crucial for terrorist campaigns in liberal democracies, whose legitimacy rests on the ability to protect citizens' lives and property (Wilkinson 1986). Success in obtaining concessions can spur terrorist groups to ratchet up their demands; this success can demonstrate to other terrorist groups that terrorism is effective (Brandt and Sandler 2009).

\section{Theoretical considerations}

We view terrorist groups as engaged in rational decision making, consistent with much of the extant literature (e.g., Enders and Sandler 1993; Landes 1978). Thus, terrorist groups allocate their resources (i.e., labor, weapons, intelligence, and base(s) of operation) to maximize their utility, which increases with the achievement of their goals. For some groups, this utility can increase with publicity for the cause as their attacks acquire notoriety. Murderous attacks against nonbelievers by religious fundamentalist groups provide utility even though no concessions are attained (Hoffman 2006). Terrorist groups allocate their resources among attack modes (e.g., assassinations, bombings, or hostage taking) in order to achieve the greatest expected marginal payoff per dollar spent (Berrebi and Lakdawalla 2007).

\footnotetext{
${ }^{4}$ Terrorist groups' goals also figured in other recent studies. Asal and Rethemeyer (2008) showed that religious fundamentalist terrorist groups were more lethal. In the context of suicide terrorism, Horowitz (2010) found that these fundamentalist terrorist groups were more apt to employ suicide terrorism. Piazza (2008) showed that terrorist groups with "universal" or "abstract" political goals were more likely to engage in suicide terrorism.
} 
When allocating their scarce resources, terrorist groups confront competing risks that may lead them to end their operations. As measured by Jones and Libicki (2008), these risks involve being defeated by police or military actions, disintegrating by internal splintering, becoming part of the political process (e.g., the Irish Republican Army in Northern Ireland), or achieving one or more goals through victory. If the terrorist group experiences none of these endings, then it remains active. Each of these competing risks is influenced in different ways by the following considerations: the terrorist groups' resources, environmental factors (e.g., the economic, political, and geographical aspects of the groups' base country or countries), the groups' orientation (i.e., their ideologies and goals), the groups' tactics (i.e., diversification and level of attacks), and government actions. Larger terrorist group memberships should reduce all competing risks, especially in terms of police or military defeat. If the terrorist group possesses multiple bases of operation, then these bases should limit the group's failure by splintering or force. For splintering, multiple bases of operation allow a terrorist group to adopt alternative orientations, which can appease various viewpoints within the group. Regarding defeat by force, multiple bases of operation mean that host countries must join forces to eliminate the terrorist group, which rarely occurs (Enders and Sandler 2012). Multiple bases may also signal greater state sponsorship, because two or more countries implicitly permit the terrorist group to reside on their soils. Intergroup competition in the base country may inhibit the terrorist groups from joining the political process or achieving victory, because the government is unlikely to appease multiple viewpoints. In terms of environmental factors, high income per capita is more apt to result in defeat for the terrorist group, because the host country has a large tax base from which to raise counterterrorism funding. In contrast, adherence to democratic principles may reduce this possibility of defeat for the terrorist group owing to tighter constraint on executive power (Li 2005). Higher elevations and thicker jungle cover provide the terrorists with more hiding opportunities, which decrease the likelihood of defeat without necessarily influencing the other competing risks. A larger base-country population is anticipated to limit the terrorist group's ability to join the political process or attain its demands owing to the likelihood of many opposing views diluting the group's political influence.

Relative to religious fundamentalists, we expect that left-wing, right-wing, and nationalist terrorist groups have a greater likelihood of joining the political process or achieving one or more of their demands. Religious fundamentalist terrorist groups pose a greater threat and challenge to the existing order. Terrorist groups with more encompassing goals, such as territorial change, empire, regime change, or social revolution, are less apt than terrorist groups desiring policy change or the status quo from joining the political process or achieving victory. Since diversification pays, terrorist groups that rely on more attack modes should limit their risks of military defeat or internal splintering. An enhanced terrorist campaign with more attacks can increase the terrorist group's resources, thereby limiting splintering and promoting political legitimacy. Larger terrorist campaigns can also motivate the targeted government to increase its counterterrorism response, which can increase the risk of defeat or splintering. In general, military and/or government spending are expected to augment terrorist groups' risk of defeat.

Our second exercise is geared toward ascertaining whether the overall risk of terrorist groups' failure differs between the era of leftist terrorist dominance (before 1990) and the era of religious fundamentalist terrorist dominance (after the start of 1990). ${ }^{5}$ Given the differing goals, ideologies, and tactics of the two types of terrorists, any differences in the risk

\footnotetext{
${ }^{5}$ Enders and Sandler (1999) showed that the pattern of transnational terrorism changed in the post-Cold War era after the early 1990s. Our second exercise is motivated, in part, by this established stylized fact, which is based on the changing nature of the dominant terrorist groups and much reduced state sponsorship.
} 
of terrorist groups' failure between the two eras should be associated with these factors. That is, elevation, jungle cover, democracy, and government spending in the base country are not anticipated to differ in their influence on terrorist groups' failure between the two eras. The same should be true for regional location. Prior to 1990, we expect the more prevalent leftwing, right-wing, and nationalist terrorist groups to be at a greater risk of failure relative to religious terrorist groups. These latter terrorist groups were just getting started and were flying under the radar before 1990. During the initial period, terrorist groups' goals-e.g., territorial change-are more conducive to these groups remaining active than in the latter period when terrorists raised the level of carnage, adopted harder-to-fulfill goals, and induced governments to be more aggressive in countering terrorism. As such, we expect the number of attacks per million persons to have a negative effect on terrorist groups' survival after 1990. Attack diversity may promote terrorist groups' longevity during the era of the leftists, but not during the era of the religious fundamentalists, when governments redoubled their efforts to destroy terrorist groups. Terrorist group competition in the base countries is more apt to reduce terrorist groups' failure rates in the latter period as governments allocated a significant portion of counterterrorism resources to defensive measures away from proactive measures. Terrorist groups with multiple bases of operations are anticipated to fare better before than after 1990, since the lesser threat posed by the leftist terrorist groups meant that base-country governments were less inclined to pool their forces to eradicate resident terrorists. After the start of 1990, terrorist groups moved some bases of operation to failed or weak states, which aided their survival chances (Enders and Sandler 2012).

\section{Methodology and data}

We first present our empirical methodology, followed by the data and their sources.

\subsection{Empirical methodology}

Similar to Carter (2012), we estimate a competing risks model, for which an active terrorist group faces alternative risks of leaving a given state. Each risk brings about a specific exit destination. Define $T_{i j}$ as the latent duration for terrorist group $i$ until it exits to destination $j$. $T_{i j}$ is not observable directly; the data instead report $T_{i}=\min \left\{T_{i 0}, T_{i 1}, \ldots, T_{i J}\right\}$, along with information on the cause of a terrorist group's ending. There are three possible destination states in our model: ending through military force or policing $(j=1)$, ending by splintering $(j=2)$, or ending by joining political process or achieving victory $(j=3)$. If a group is still active by the end of the sample period $(j=0)$, then the latent durations are right-censored.

We apply multinomial logit regressions to estimate the models (Long 2012; Train 2009). Let $E_{i h}$ indicate a specific exit destination that terrorist group $i$ experiences in a given year $h$, so that $E_{i h}=j$ if $T_{i}=T_{i j}, j=0,1,2,3$. Then the probability that a terrorist group $i$ experiences event $j$ is

$$
P\left(E_{i h}=j \mid \mathbf{x}_{i h}, t_{h}\right)=\exp \left(\mathbf{x}_{i h} \boldsymbol{\alpha}_{j}+\phi(h)\right) /\left[1+\sum_{k=1}^{J} \exp \left(\mathbf{x}_{i h} \boldsymbol{\alpha}_{k}+\phi(h)\right)\right],
$$

where $\mathbf{x}_{i h}$ is a vector of explanatory variables for terrorist group $i$ at year $h ; \boldsymbol{\alpha}_{j}$ is a vector of relevant parameters; and $\phi(h)$ is an unspecified duration function. We use a quadratic duration function, $\phi(h)=\phi_{0} t_{h}+\phi_{1} t_{h}^{2}\left(h=1,2, \ldots\right.$, and $\left.t_{1}=0\right)$, for the main regression models and apply a piecewise constant specification as a robustness check. 
Next, we separate our sample into two subsamples for terrorist groups that formed during 1970-1989 and for those that formed during 1990-2007. We implement a logit regression to estimate discrete-time hazard models for each subsample (Allison 1982; Jenkins 1995). Let $T_{i}$ denote a random variable measuring the duration of a terrorist group's life in years. The probability of a terrorist organization ending in a given time interval, $\left[t_{h}, t_{h+1}\right), h=1,2, \ldots$, and $t_{1}=0$, is

$$
P\left(T_{i}<t_{h+1} \mid T_{i} \geq t_{h}, \mathbf{x}_{i h}\right)=\exp \left(\mathbf{x}_{i h} \boldsymbol{\lambda}+\phi(h)\right) /\left[1+\exp \left(\mathbf{x}_{i h} \lambda+\phi(h)\right)\right] .
$$

We also implement the random-effects logit regression to account for unobserved heterogeneity.

\subsection{Data}

Information on terrorist groups' characteristics, their fates, and their base country or countries of operation comes from Jones and Libicki (2008). Data on terrorist groups' attacks are obtained from RAND Database of Worldwide Terrorism Incidents (RAND 2012). Socioeconomic, political, and geographical data on the base country of operations are taken from a number of sources, as detailed below. These datasets are merged into a panel of 586 terrorist organizations for 1970-2007. At times, the same terrorist group has alternative names reported in Jones and Libicki (2008) and in RAND (2012); hence, we painstakingly checked terrorist groups' names and made any necessary revisions to ensure that they matched prior to merging the two datasets.

We construct group-specific variables using Jones and Libicki's (2008) data, which provided information on when terrorist groups started, when they ended (if relevant), and how they ended. ${ }^{6}$ This information is then used to create the dependent variable, which, for a given year, is 0 if a group is active, 1 if a group is defeated by police or military, 2 if a group splinters and disintegrates from internal factors, and 3 if a group ends either by joining the political process or achieving victory. Only 25 sample terrorist groups ended with victory. When joining the political process or obtaining victory, terrorist groups achieved some, but not necessarily all, of their goals. We later perform robustness analysis and show that our results are not sensitive to the exclusion of groups that ended in victory. For the two subperiod samples, we use a dichotomous dependent variable, which is 0 if the terrorist group is active and 1 if the group ends in any of the ways indicated above. The strength of a terrorist group is proxied by the logarithm of the group's membership size at its peak, $\log ($ size $)$. Using Jones and Libicki's (2008) classification of terrorist groups' ideologies, we create four dummy variables to indicate Left wing, Nationalist, Right wing, and Religious terrorist groups. Additionally, we introduce four dummy variables to control for the main goals of terrorist groups, as indicated in Jones and Libicki (2008). The multi-goal variable, ERCSR, equals 1 if a terrorist group's goal desires an empire, regime change, or social revolution, and 0 otherwise. We combine these three goals since they are all ambitious and broad-based. The three other dummy variables denote policy change (Policy change), territorial change (Territ. change), and status quo (Status Quo). In our sample, the vast majority of terrorist groups $(73 \%)$ had a single base country of operation, with less than $3 \%$ of terrorist groups having more than three bases. The dummy variable Multiple bases equals 1 if a terrorist

\footnotetext{
${ }^{6}$ Relative to Jones and Libicki (2008), we change the active status of two terrorist groups-the Ulster Defence Association and the Ulster Volunteer Force-as having joined the political process in 2007 when they abandoned terrorism.
} 
group had two or more bases of operation, and equals 0 otherwise. To control for competition among terrorist groups that are based in the same country, we compute the average number of other terrorist groups located in the same country and denote it by Group compet.

Data on the number and type of transnational terrorist incidents come from RAND (2012). We analyze transnational terrorist attacks because RAND does not report domestic terrorism prior to 1998. If we were to use the Global Terrorism Database (GTD) (National Consortium for the Study of Terrorism and Responses to Terrorism 2009), which has information on both domestic and transnational terrorism, the number of terrorist groups in our sample would be severely reduced. To capture the intensity of terrorist groups' campaigns, we compute the number of transnational terrorist incidents per million people (Terr/POP) for each group. Data on population are taken from Penn World Table Version 7.0 (Heston et al. 2011). Using information on seven types of terrorist attacks (bombings and arson, kidnappings, barricade and hostage taking, skyjackings, assassinations, armed attacks, and other attacks), we compute the diversity of terrorist attacks index (Attack diversity), which is one minus the Hirschman-Herfindahl index. This index ranges between 0 and 1, with larger values signifying greater diversity_-see the computation method in Blomberg et al. (2011).

We also include variables associated with a terrorist group's base country of operation, which are averaged across base countries for groups with more than one base. The logarithm of real per capita GDP $[\log (G D P / P O P)]$, the logarithm of population $[\log (P O P)]$, and government spending as a percentage of GDP (Gov. spending) are obtained for each year from the Penn World Table Version 7.0. Government spending partially captures the effect of counterterrorism; unfortunately, data on counterterrorism expenditure per se are not available. We also use military expenditure as a percentage of GDP (Military expenditure) (World Bank 2010) as an alternative proxy for counterterrorism efforts. Because military spending data are not available for all sample years, we resort to this variable only in the robustness analysis after the beginning of 1990. The Polity variable is included to control for the degree of democracy (Marshall and Jaggers 2009), and ranges between -10 and +10 , with larger positive values indicative of stronger democracies. We also add an ethnic fractionalization index (Ethnic frac.), in which larger values imply greater ethnic diversity (Alesina et al. 2003). Finally, we include a host of variables to control for geological and geographical characteristics of base countries. We construct regional dummy variables for East Asia and Pacific, Europe and Central Asia, Latin America and Caribbean, Middle East and North Africa, North America, South Asia, and sub-Saharan Africa, based on World Bank (2010) defined regions. We also include the logarithm of a country's average elevation $[\log ($ elevation) $]$, a country's percentage share of tropical land territory (Tropics), and a dummy variable indicating a country's lack of direct access to international waters (Landlocked) (Gallup et al. 1999a, 1999b).

Table 1 presents information on terrorist groups' fates and characteristics. Around $36 \%$ of sample terrorist groups were active in 2007, $19 \%$ were defeated militarily, $22 \%$ splintered, and $23 \%$ joined the political process or achieved victory. On average, active terrorist groups were larger in size than those that ended in defeat or splintered. These active terrorist groups also faced stiffer competition in terms of the number of other groups in the same base country. In contrast, terrorist groups that ended by political participation or victory were the largest in size, but had fewer competitive terrorist groups in their base country. Splintered terrorist groups confronted strong competition, but were small in membership size. The majority of terrorist groups that sought empire, regime change, or social revolution were active at the end of the sample period. The same held true for terrorist groups that desired territorial change. However, terrorist groups that sought changing a policy or maintaining the status quo had a greater likelihood to end by joining the political forum or achieving victory. This indicates a proclivity of governments to concede smaller demands to terrorist groups. 
Table 1 Terrorist groups' characteristics and groups' fate

\begin{tabular}{|c|c|c|c|c|c|c|c|c|}
\hline \multirow[t]{2}{*}{ Groups' fate } & \multicolumn{4}{|c|}{ Entire sample groups } & \multicolumn{2}{|c|}{$\begin{array}{l}\text { Groups started before } \\
1990\end{array}$} & \multicolumn{2}{|c|}{$\begin{array}{l}\text { Groups started after } \\
1990\end{array}$} \\
\hline & Number & Percentage & $\begin{array}{l}\text { Mean } \\
\text { competition }\end{array}$ & $\begin{array}{l}\text { Mean } \\
\text { peak size }\end{array}$ & Number & Percentage & Number & Percentage \\
\hline Active & 213 & 36.35 & 11.45 & 798.03 & 70 & 23.73 & 143 & 49.14 \\
\hline $\begin{array}{l}\text { Military/ } \\
\text { Policing }\end{array}$ & 110 & 18.77 & 5.01 & 362.64 & 77 & 26.10 & 33 & 11.34 \\
\hline Splintering & 131 & 22.35 & 8.24 & 121.98 & 66 & 22.37 & 65 & 22.34 \\
\hline $\begin{array}{l}\text { Politics/ } \\
\text { Victory }\end{array}$ & 132 & 22.53 & 3.97 & 1173.18 & 82 & 27.80 & 50 & 17.18 \\
\hline Total & 586 & 100 & & & 295 & 100 & 291 & 100 \\
\hline \multirow[t]{2}{*}{ Groups' fate } & \multicolumn{4}{|c|}{ Entire sample: number of groups by type } & \multicolumn{4}{|c|}{ Entire sample: number of groups by goal } \\
\hline & $\begin{array}{l}\text { Left } \\
\text { wing }\end{array}$ & Nationalist & Religious & $\begin{array}{l}\text { Right } \\
\text { wing }\end{array}$ & ERCSR & $\begin{array}{l}\text { Policy } \\
\text { change }\end{array}$ & $\begin{array}{l}\text { Territori } \\
\text { change }\end{array}$ & $\begin{array}{l}\text { Status } \\
\text { quo }\end{array}$ \\
\hline Active & 50 & 79 & 78 & 6 & 103 & 21 & 85 & 4 \\
\hline $\begin{array}{l}\text { Military/ } \\
\text { Policing }\end{array}$ & 57 & 32 & 15 & 6 & 65 & 20 & 22 & 3 \\
\hline Splintering & 47 & 55 & 26 & 3 & 66 & 28 & 34 & 3 \\
\hline $\begin{array}{l}\text { Politics/ } \\
\text { Victory }\end{array}$ & 63 & 52 & 3 & 14 & 47 & 49 & 24 & 12 \\
\hline
\end{tabular}

Note: ERCSR denotes Empire, Regime change, or Social Revolution

About $37 \%$ of the sample terrorist groups were left-wing ideologically, $37 \%$ were nationalist, $21 \%$ were religious, and $5 \%$ were right wing. The majority of active terrorist groups were either nationalist or religious. This holds true whether we look across or within ideologies. The religious terrorist groups were relatively young; around $69 \%$ of these groups started after the beginning of 1990. Only three religious terrorist groups ended by joining the political process, and these groups were established before 1990. No religious terrorist group ended by victory in our sample. In contrast, larger shares of left-wing and right-wing terrorist groups ended by joining the political process or achieving victory.

Our sample consists of 295 terrorist groups that started before 1990, and 291 terrorist groups that started in 1990 or thereafter. More than half of active terrorist groups began after the start of 1990. In both subperiods, left-wing and nationalist terrorist groups outnumbered religious and right-wing terrorist groups. The larger share of left-wing and nationalist terrorist groups began before 1990, whereas the majority of religious and right-wing terrorist groups started after 1990. This confirms the rising dominance of religious fundamentalist terrorist groups after 1990.

\section{Results}

Table 2 presents two specifications of the multinomial logit regression results. Model 1 includes group-specific variables along with base-country economic, demographic, and political variables. Model 2 adds regional and geographic variables, associated with the base countries. For each model, columns "Military defeat," "Splintering," and "Politics/Victory" 
Table 2 Multinomial logit regressions of terrorist groups' endings, 1970-2007

\begin{tabular}{|c|c|c|c|c|c|c|}
\hline \multirow[t]{2}{*}{ Variable } & \multicolumn{3}{|l|}{ Model 1} & \multicolumn{3}{|l|}{ Model 2} \\
\hline & $\begin{array}{l}\text { Military } \\
\text { defeat }\end{array}$ & Splintering & $\begin{array}{l}\text { Politics/ } \\
\text { victory }\end{array}$ & $\begin{array}{l}\text { Military } \\
\text { defeat }\end{array}$ & Splintering & $\begin{array}{l}\text { Politics/ } \\
\text { victory }\end{array}$ \\
\hline $\log ($ size $)$ & $\begin{array}{l}-0.423^{* * *} \\
(0.075)\end{array}$ & $\begin{array}{l}-0.670^{* * *} \\
(0.098)\end{array}$ & $\begin{array}{l}-0.193^{* * *} \\
(0.057)\end{array}$ & $\begin{array}{l}-0.413^{* * *} \\
(0.076)\end{array}$ & $\begin{array}{l}-0.678^{* * *} \\
(0.102)\end{array}$ & $\begin{array}{l}-0.195^{* * *} \\
(0.062)\end{array}$ \\
\hline Left wing & $\begin{array}{l}0.492 \\
(0.341)\end{array}$ & $\begin{array}{l}-0.519 \\
(0.336)\end{array}$ & $\begin{array}{l}1.786^{* * *} \\
(0.612)\end{array}$ & $\begin{array}{l}0.713^{*} \\
(0.374)\end{array}$ & $\begin{array}{l}-0.639^{*} \\
(0.373)\end{array}$ & $\begin{array}{l}1.535^{* *} \\
(0.644)\end{array}$ \\
\hline Nationalist & $\begin{array}{l}0.758^{* *} \\
(0.367)\end{array}$ & $\begin{array}{l}0.460 \\
(0.319)\end{array}$ & $\begin{array}{l}2.453^{* * *} \\
(0.618)\end{array}$ & $\begin{array}{l}0.615 \\
(0.399)\end{array}$ & $\begin{array}{l}0.459 \\
(0.346)\end{array}$ & $\begin{array}{l}2.273^{* * *} \\
(0.644)\end{array}$ \\
\hline Right wing & $\begin{array}{l}0.655 \\
(0.541)\end{array}$ & $\begin{array}{l}-0.656 \\
(0.666)\end{array}$ & $\begin{array}{l}2.224^{* * *} \\
(0.668)\end{array}$ & $\begin{array}{l}0.808 \\
(0.568)\end{array}$ & $\begin{array}{l}-0.685 \\
(0.687)\end{array}$ & $\begin{array}{l}2.002^{* * *} \\
(0.706)\end{array}$ \\
\hline ERCSR & $\begin{array}{l}0.183 \\
(0.649)\end{array}$ & $\begin{array}{l}0.640 \\
(0.660)\end{array}$ & $\begin{array}{l}-1.010^{* * *} \\
(0.389)\end{array}$ & $\begin{array}{l}0.249 \\
(0.663)\end{array}$ & $\begin{array}{l}0.398 \\
(0.687)\end{array}$ & $\begin{array}{l}-0.951^{* *} \\
(0.424)\end{array}$ \\
\hline Policy change & $\begin{array}{l}-0.041 \\
(0.671)\end{array}$ & $\begin{array}{l}0.299 \\
(0.674)\end{array}$ & $\begin{array}{l}0.070 \\
(0.386)\end{array}$ & $\begin{array}{l}-0.190 \\
(0.697)\end{array}$ & $\begin{array}{l}0.166 \\
(0.700)\end{array}$ & $\begin{array}{l}0.337 \\
(0.430)\end{array}$ \\
\hline Territ. change & $\begin{array}{l}-0.665 \\
(0.684)\end{array}$ & $\begin{array}{l}-0.247 \\
(0.659)\end{array}$ & $\begin{array}{l}-1.843^{* * *} \\
(0.410)\end{array}$ & $\begin{array}{l}-0.555 \\
(0.694)\end{array}$ & $\begin{array}{l}-0.493 \\
(0.682)\end{array}$ & $\begin{array}{l}-1.478^{* * *} \\
(0.457)\end{array}$ \\
\hline Terr/POP & $\begin{array}{l}0.046 \\
(0.215)\end{array}$ & $\begin{array}{l}0.135 \\
(0.103)\end{array}$ & $\begin{array}{l}0.003 \\
(0.272)\end{array}$ & $\begin{array}{l}0.086 \\
(0.185)\end{array}$ & $\begin{array}{l}0.131 \\
(0.109)\end{array}$ & $\begin{array}{l}0.045 \\
(0.253)\end{array}$ \\
\hline Multiple bases & $\begin{array}{l}-0.461^{*} \\
(0.248)\end{array}$ & $\begin{array}{l}-0.588^{* *} \\
(0.262)\end{array}$ & $\begin{array}{l}-0.189 \\
(0.230)\end{array}$ & $\begin{array}{l}-0.680^{* *} \\
(0.279)\end{array}$ & $\begin{array}{l}-0.496^{*} \\
(0.280)\end{array}$ & $\begin{array}{l}-0.410 \\
(0.274)\end{array}$ \\
\hline Group compet. & $\begin{array}{l}-0.045^{*} \\
(0.024)\end{array}$ & $\begin{array}{l}0.029 \\
(0.018)\end{array}$ & $\begin{array}{l}-0.076^{* * *} \\
(0.027)\end{array}$ & $\begin{array}{l}-0.011 \\
(0.030)\end{array}$ & $\begin{array}{l}0.046^{*} \\
(0.026)\end{array}$ & $\begin{array}{l}-0.032 \\
(0.031)\end{array}$ \\
\hline Attack diversity & $\begin{array}{l}-0.170 \\
(1.044)\end{array}$ & $\begin{array}{l}-2.694 \\
(1.953)\end{array}$ & $\begin{array}{l}-1.940 \\
(1.361)\end{array}$ & $\begin{array}{l}-0.207 \\
(1.044)\end{array}$ & $\begin{array}{l}-2.617 \\
(1.958)\end{array}$ & $\begin{array}{l}-1.733 \\
(1.386)\end{array}$ \\
\hline $\log (G D P / P O P)$ & $\begin{array}{l}0.347^{* *} \\
(0.143)\end{array}$ & $\begin{array}{l}0.072 \\
(0.144)\end{array}$ & $\begin{array}{l}0.023 \\
(0.126)\end{array}$ & $\begin{array}{l}-0.144 \\
(0.229)\end{array}$ & $\begin{array}{l}0.032 \\
(0.222)\end{array}$ & $\begin{array}{l}0.246 \\
(0.213)\end{array}$ \\
\hline $\log (P O P)$ & $\begin{array}{l}0.122 \\
(0.096)\end{array}$ & $\begin{array}{l}-0.213^{* *} \\
(0.085)\end{array}$ & $\begin{array}{l}-0.240^{* * *} \\
(0.086)\end{array}$ & $\begin{array}{l}0.086 \\
(0.131)\end{array}$ & $\begin{array}{l}-0.182 \\
(0.125)\end{array}$ & $\begin{array}{l}-0.262^{* *} \\
(0.129)\end{array}$ \\
\hline Gov. spending & $\begin{array}{l}3.122 \\
(1.990)\end{array}$ & $\begin{array}{l}-0.901 \\
(2.614)\end{array}$ & $\begin{array}{l}1.672 \\
(1.817)\end{array}$ & $\begin{array}{l}4.001^{*} \\
(2.372)\end{array}$ & $\begin{array}{l}-0.921 \\
(2.710)\end{array}$ & $\begin{array}{l}1.801 \\
(1.939)\end{array}$ \\
\hline Polity & $\begin{array}{l}-0.041^{* *} \\
(0.020)\end{array}$ & $\begin{array}{l}0.008 \\
(0.021)\end{array}$ & $\begin{array}{l}0.021 \\
(0.020)\end{array}$ & $\begin{array}{l}-0.019 \\
(0.023)\end{array}$ & $\begin{array}{l}0.004 \\
(0.025)\end{array}$ & $\begin{array}{l}0.008 \\
(0.022)\end{array}$ \\
\hline Ethnic frac. & $\begin{array}{l}0.805 \\
(0.552)\end{array}$ & $\begin{array}{l}0.037 \\
(0.602)\end{array}$ & $\begin{array}{l}0.501 \\
(0.487)\end{array}$ & $\begin{array}{l}1.945^{* *} \\
(0.766)\end{array}$ & $\begin{array}{l}0.233 \\
(0.833)\end{array}$ & $\begin{array}{l}-0.358 \\
(0.741)\end{array}$ \\
\hline East As. \& Pa. & & & & $\begin{array}{l}0.320 \\
(0.597)\end{array}$ & $\begin{array}{l}-0.169 \\
(0.726)\end{array}$ & $\begin{array}{l}0.548 \\
(0.695)\end{array}$ \\
\hline Eur.\& Cen. As. & & & & $\begin{array}{l}-0.268 \\
(0.406)\end{array}$ & $\begin{array}{l}0.654 \\
(0.416)\end{array}$ & $\begin{array}{l}1.030^{* *} \\
(0.439)\end{array}$ \\
\hline Lat. Am. \& Car. & & & & $\begin{array}{l}0.485 \\
(0.463)\end{array}$ & $\begin{array}{l}-0.407 \\
(0.632)\end{array}$ & $\begin{array}{l}1.598^{* * *} \\
(0.548)\end{array}$ \\
\hline North America & & & & $\begin{array}{l}0.668 \\
(0.472)\end{array}$ & $\begin{array}{l}-0.688 \\
(0.725)\end{array}$ & $\begin{array}{l}0.145 \\
(0.552)\end{array}$ \\
\hline South Asia & & & & $\begin{array}{l}-1.061 \\
(0.720)\end{array}$ & $\begin{array}{l}-0.666 \\
(0.736)\end{array}$ & $\begin{array}{l}1.435^{* *} \\
(0.722)\end{array}$ \\
\hline sub-Sah. Africa & & & & $\begin{array}{l}-0.336 \\
(0.688)\end{array}$ & $\begin{array}{l}-0.060 \\
(0.872)\end{array}$ & $\begin{array}{l}1.997^{* * *} \\
(0.613)\end{array}$ \\
\hline $\log ($ elevation $)$ & & & & $\begin{array}{l}-0.838^{* * *} \\
(0.199)\end{array}$ & $\begin{array}{l}0.535^{* *} \\
(0.251)\end{array}$ & $\begin{array}{l}0.091 \\
(0.205)\end{array}$ \\
\hline
\end{tabular}


Table 2 (Continued)

\begin{tabular}{|c|c|c|c|c|c|c|}
\hline \multirow[t]{2}{*}{ Variable } & \multicolumn{3}{|l|}{ Model 1} & \multicolumn{3}{|l|}{ Model 2} \\
\hline & $\begin{array}{l}\text { Military } \\
\text { defeat }\end{array}$ & Splintering & $\begin{array}{l}\text { Politics/ } \\
\text { victory }\end{array}$ & $\begin{array}{l}\text { Military } \\
\text { defeat }\end{array}$ & Splintering & $\begin{array}{l}\text { Politics/ } \\
\text { victory }\end{array}$ \\
\hline Tropics & & & & $\begin{array}{l}-1.530^{* * *} \\
(0.533)\end{array}$ & $\begin{array}{l}0.539 \\
(0.647)\end{array}$ & $\begin{array}{l}-0.247 \\
(0.492)\end{array}$ \\
\hline Landlocked & & & & $\begin{array}{l}0.723 \\
(0.513)\end{array}$ & $\begin{array}{l}0.376 \\
(0.467)\end{array}$ & $\begin{array}{l}1.218^{* * *} \\
(0.360)\end{array}$ \\
\hline Time & $\begin{array}{l}-0.048 \\
(0.038)\end{array}$ & $\begin{array}{l}-0.334^{* * *} \\
(0.047)\end{array}$ & $\begin{array}{l}-0.194^{* * *} \\
(0.036)\end{array}$ & $\begin{array}{l}-0.031 \\
(0.039)\end{array}$ & $\begin{array}{l}-0.324^{* * *} \\
(0.047)\end{array}$ & $\begin{array}{l}-0.195^{* * *} \\
(0.037)\end{array}$ \\
\hline Time squared & $\begin{array}{l}0.001 \\
(0.001)\end{array}$ & $\begin{array}{l}0.009 * * * \\
(0.001)\end{array}$ & $\begin{array}{l}0.006^{* * *} \\
(0.001)\end{array}$ & $\begin{array}{l}0.001 \\
(0.001)\end{array}$ & $\begin{array}{l}0.009^{* * *} \\
(0.001)\end{array}$ & $\begin{array}{l}0.006^{* * *} \\
(0.001)\end{array}$ \\
\hline Constant & $\begin{array}{l}-6.692^{* * *} \\
(1.985)\end{array}$ & $\begin{array}{l}1.487 \\
(2.014)\end{array}$ & $\begin{array}{l}-0.699 \\
(1.705)\end{array}$ & $\begin{array}{l}2.793 \\
(2.937)\end{array}$ & $\begin{array}{l}-2.070 \\
(3.288)\end{array}$ & $\begin{array}{l}-4.055 \\
(3.070)\end{array}$ \\
\hline$N$ & & 5605 & & & 5576 & \\
\hline
\end{tabular}

Notes: Significance levels: ${ }^{* * *}$ is $<0.01,{ }^{* *}$ is $<0.05$, and ${ }^{*}$ is $<0.10$. Standard errors are in parentheses. ERCSR denotes Empire, Regime change, or Social Revolution

display the variables' estimates of the probability of a terrorist group ending by military force or policing, by splintering, or by joining the political process or achieving victory, respectively.

Terrorist group size has a negative and statistically significant impact on any of the alternative ways that terrorist groups may end. On average, larger terrorist groups are less likely to end, which agrees with our theoretical expectations and past findings (see, e.g., Blomberg et al. 2011; Gaibulloev and Sandler 2013; Jones and Libicki 2008; Phillips 2013). The statistical significance of other variables differs across the three types of endings, which justifies the novelty of our exercise and makes it difficult to compare our findings to those in the literature, where these different endings are not distinguished. Left-wing, nationalist, and right-wing terrorist groups are more likely than religious groups to end operations through politics/victory, which concurs with our prior expectation; however, the effect of ideology is not robust for military defeat and splintering. ${ }^{7}$ In Model 2, the effect of a left-wing ideology is positive and significant on the probability of groups' military defeat, but it is negative and statistically significant on the likelihood of groups' splintering. The impact of a nationalist ideology is positive and statistically significant on the probability of military defeat in Model 1. Consistent with our priors, terrorist groups seeking empire, regime change, or social revolution (ERCSR) and terrorist groups aiming for territorial change are less likely to conclude their operations through politics/victory than terrorist groups seeking to maintain the status quo. Broad and demanding concessions are not granted, presumably owing to large concomitant costs imposed on the government. The impact of the policy-change goal is not a statistically significant determinant of the politics/victory outcome for terrorist groups. For both models, the terrorist groups' goal variables are not statistically significant determinants of military defeat or splintering. Terrorist groups with more than one base of operation are less apt to be eliminated by military force or to splinter, consistent with our hypothesis. Multiple bases of operations provide the terrorist organization with resilience to

\footnotetext{
${ }^{7}$ It is not appropriate to compare our findings to those of Carter (2012), because the competing risks categories and many of the variables in his article and our analysis differ.
} 


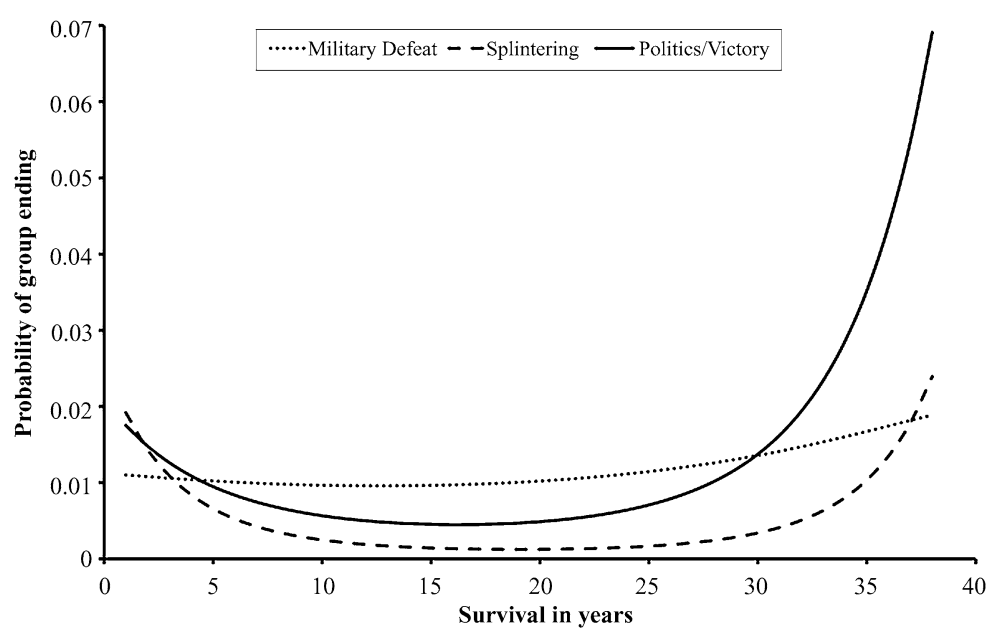

Fig. 1 Predicted probabilities of terrorist groups' endings

external and internal threats; however, there is no statistically significant evidence to suggest that these bases are conducive to the terrorist group joining the political process or achieving victory.

Terrorist groups, based in countries with larger populations, are less apt to join the political process or achieve victory, owing to more people holding other viewpoints. For our sample period, terrorist groups based in Europe and Central Asia, Latin America and Caribbean, South Asia, and sub-Saharan Africa are more inclined to conclude by joining the political process or achieving victory than terrorist groups based in the Middle East and North Africa. This suggests a harder line against assimilating terrorist groups in the political process in the latter region. Base-country elevation significantly reduces terrorist groups' probability of military defeat, but it significantly raises their probability of splintering. This may follow because elevation provides cover, which may ward off military defeat, while higher elevation is associated with harsh conditions, which may foster internal strife within the group. On average, terrorist groups based in countries with larger tropical areas are less likely to end through military defeat presumably because of more cover. When terrorist groups are based in landlocked countries, the prospect for joining the political process or achieving victory (politics/victory) is bolstered, which may be due to geographical isolation encouraging compromise. The impacts of other variables are either not statistically significant or not robust across models.

Before some age threshold, terrorist groups face a decreasing likelihood of ending by splintering or politics/victory as they grow older. However, after this threshold, these groups are increasingly prone to end by splintering or politics/victory as they grow older. The impact of time on terrorist groups experiencing military defeat is not statistically significant. The relationship between terrorist groups' age and their endings is captured in Fig. 1, which indicates the predicted probability of alternative endings at different terrorist groups' ages, holding other variables at their mean. In their early years, terrorist groups have a roughly equal chance of ending by splintering or by politics/victory. As these groups age, their probability of joining the political process or achieving victory becomes ever larger than the likelihood of splintering. In contrast, the likelihood of military defeat increases only slightly as terrorist groups age. 
Table 3 Marginal effects for Model 2 in Table 2

\begin{tabular}{|c|c|c|c|c|c|c|}
\hline \multirow[t]{2}{*}{ Variable } & \multicolumn{2}{|l|}{ Military defeat } & \multicolumn{2}{|l|}{ Splintering } & \multicolumn{2}{|l|}{ Politics/victory } \\
\hline & Marginal effect & p-value & Marginal effect & $\mathrm{p}$-value & Marginal effect & $\mathrm{p}$-value \\
\hline $\log (\text { size })^{*}$ & -0.004 & 0.000 & -0.003 & 0.000 & -0.002 & 0.004 \\
\hline Left wing* & 0.008 & 0.105 & -0.003 & 0.072 & 0.018 & 0.064 \\
\hline Nationalist* & 0.006 & 0.176 & 0.002 & 0.261 & 0.028 & 0.009 \\
\hline ERCSR $^{*}$ & 0.003 & 0.705 & 0.002 & 0.570 & -0.008 & 0.035 \\
\hline Territ. change* & -0.005 & 0.423 & -0.002 & 0.479 & -0.012 & 0.003 \\
\hline Multiple bases* & -0.007 & 0.015 & -0.002 & 0.097 & -0.003 & 0.140 \\
\hline Group compet. & 0.000 & 0.725 & 0.000 & 0.093 & 0.000 & 0.298 \\
\hline $\log (P O P)$ & 0.001 & 0.499 & -0.001 & 0.168 & -0.002 & 0.054 \\
\hline Gov. spending & 0.042 & 0.098 & -0.004 & 0.719 & 0.015 & 0.365 \\
\hline Ethnic frac. & 0.020 & 0.013 & 0.001 & 0.795 & -0.003 & 0.608 \\
\hline Eur. \& Cen. As.* & -0.003 & 0.458 & 0.003 & 0.203 & 0.012 & 0.081 \\
\hline Lat. Am. \& Car.* & 0.006 & 0.394 & -0.002 & 0.433 & 0.025 & 0.088 \\
\hline South Asia* & -0.009 & 0.056 & -0.002 & 0.277 & 0.020 & 0.206 \\
\hline $\log ($ elevation $)$ & -0.009 & 0.000 & 0.002 & 0.043 & 0.001 & 0.634 \\
\hline Tropics & -0.016 & 0.006 & 0.002 & 0.397 & -0.002 & 0.635 \\
\hline Landlocked* & 0.007 & 0.169 & 0.002 & 0.453 & 0.010 & 0.002 \\
\hline
\end{tabular}

Notes: Statistically significant estimates and their probability values are boldfaced. ERCSR denotes Empire, Regime change, or Social Revolution. * denotes dummy variable. The effect for dummy variable is the discrete change from the base level. Only statistically significant variables are presented to save space. See Model 2 in Table 2 for the complete specification

The marginal effects for Model 2 are presented in Table 3, where only the variables with one or more statistically significant effects are displayed to conserve space. The terrorist groups' probability of ending in the three alternative ways reduces by about 0.02 to 0.04 percentage points in response to a $10 \%$ increase in group size. The data on terrorist group size are given in increments of 10,100,1,000, and 10,000. We also examine the predicted probability of various endings for different terrorist group sizes, holding the other variables at their mean. The predicted probability of ending militarily decreases from 0.03 to 0.01 , or by $66.7 \%$, as group size increases from 10 to 100. A similar change in predicted probability characterizes splintering. For politics/victory, the change in the predicted likelihood is around $28.6 \%$. The reduction in the predicted probability is more pronounced as terrorist groups become large; e.g., the likelihood of defeat by force reduces to 0.002 for a terrorist group of 10,000 members. Left-wing and nationalist terrorist groups are about two and three percentage points more likely, respectively, to join the political process or achieve victory than a religious fundamentalist group. Terrorist groups that seek ERCSR or territorial change are one percentage point less inclined to terminate their operations by politics/victory than groups that aim to maintain the status quo. Other statistically significant marginal impacts in Table 3 are interpreted in a similar fashion.

Table 4 indicates the terrorist groups' predicted probabilities of ending through politics/victory, based on their ideologies and goals (i.e., ERCSR and territorial change). Among terrorist groups that desire ERCSR, nationalist groups have the largest likelihood of ending by politics/victory. Religious terrorist groups have the smallest probability of ending by politics/victory; however, the predicted probability is not statistically significant. Left-wing and right-wing terrorist groups desiring ERCSR have larger likelihoods of concluding through 
Table 4 Predicted probabilities of ending via politics/victory by ideology and goal

\begin{tabular}{lrrrr}
\hline Ideology & \multicolumn{2}{l}{ Goal } & & \\
\cline { 2 - 4 } & ERCSR & p-value & Territorial change & p-value \\
\hline Religious & 0.002 & 0.103 & 0.001 & 0.134 \\
Left wing & 0.009 & 0.000 & 0.005 & 0.007 \\
Nationalist & 0.018 & 0.000 & 0.011 & 0.000 \\
Right wing & 0.014 & 0.009 & 0.008 & 0.021 \\
Religious - Left wing & -0.007 & 0.004 & -0.004 & 0.025 \\
Religious - Nationalist & -0.016 & 0.001 & -0.010 & 0.000 \\
Religious - Right wing & -0.012 & 0.026 & -0.007 & 0.041 \\
\hline
\end{tabular}

Notes: ERCSR denotes Empire, Regime change, or Social Revolution. The cell corresponding to Religious and ERCSR is computed by holding other ideology and goal variables at zero and all other variables at their means. Other predicted probabilities are computed similarly

politics/victory than religious terrorist groups, and this difference in predicted probabilities is statistically significant. Similarly, for terrorist groups seeking territorial change, the predicted probability of politics/victory is smaller for religious terrorist groups than for nationalist, right-wing, or left-wing terrorist groups. These differences in predicted probabilities are statistically significant.

We next perform a number of robustness checks. When we remove the 25 terrorist groups that ended in victory from the politics/victory category, the results remain essentially unchanged. Because of data availability concerns, our sample begins in 1970 even though some sample terrorist groups started their operations prior to 1970 . When we exclude these pre-1970 groups, the results generally hold (available upon request).

In Table 2, duration dependence is specified as a quadratic. To investigate the sensitivity of our results to this time-dependent specification, we re-estimate Model 2 of Table 2 using a piecewise constant specification. These regression estimates correspond to Model 1 of Table 5, where our primary results are maintained. A potential endogeneity issue may arise with some variables; e.g., the portion of government spending allocated to national security may be affected by the terrorist groups' fates. Since finding proper instruments is a formidable challenge, we re-estimate Model 2 of Table 2 using lagged values of all timevarying variables—see Model 2 in Table $5 .^{8}$ For the military defeat outcome, all previous results hold except for ethnic fractionalization. Furthermore, some ideological variables, GDP per capita, and regional dummy variables become statistically significant. In the case of internal splintering, the left-wing, multiple bases, and elevation variables are no longer statistically significant. Group size, ERCSR, and landlocked variables are not statistically significant determinants of joining the political process or achieving victory, but GDP per capita and polity become statistically significant determinants.

In the literature, a state sponsorship variable was found to be a statistically significant determinant of terrorist groups' duration (Carter 2012; Phillips 2013). We use data from Phillips (2013) to construct a state sponsorship dummy variable, which is 1 if a terrorist group received state support at some point in time, and 0 otherwise. We re-estimate Table 2 (and later Table 6) by including our state sponsorship variable. In so doing, we note that

\footnotetext{
${ }^{8}$ Group size is also potentially endogenous, but we cannot lag this variable, since we have only a single peak size measurement for each terrorist group.
} 
Table 5 Robustness analysis, 1970-2007

\begin{tabular}{|c|c|c|c|c|c|c|}
\hline \multirow[t]{2}{*}{ Variable } & \multicolumn{3}{|l|}{ Model 1} & \multicolumn{3}{|l|}{ Model 2} \\
\hline & $\begin{array}{l}\text { Military } \\
\text { defeat }\end{array}$ & Splintering & $\begin{array}{l}\text { Politics/ } \\
\text { victory }\end{array}$ & $\begin{array}{l}\text { Military } \\
\text { defeat }\end{array}$ & Splintering & $\begin{array}{l}\text { Politics/ } \\
\text { victory }\end{array}$ \\
\hline $\log ($ size $)$ & $-0.402^{* * *}$ & $-0.828^{* * *}$ & $-0.226^{* * *}$ & $-0.353^{* * *}$ & $-0.497^{* * *}$ & -0.039 \\
\hline Left wing & $0.869^{* *}$ & $-0.728^{*}$ & $1.713^{* * *}$ & $0.967^{* *}$ & 0.644 & $1.207^{*}$ \\
\hline Nationalist & $0.717^{*}$ & $0.715^{* *}$ & $2.652^{* * *}$ & $0.884^{*}$ & $0.944^{*}$ & $1.798^{* *}$ \\
\hline Right wing & $0.979 *$ & -0.735 & $2.179^{* * *}$ & $1.237^{* *}$ & 0.721 & $2.208^{* * *}$ \\
\hline ERCSR & 0.215 & -0.030 & $-1.067^{* *}$ & 0.097 & 0.389 & -0.572 \\
\hline Policy change & -0.268 & -0.231 & 0.325 & -0.411 & 0.650 & 0.663 \\
\hline Territ. change & -0.519 & $-1.184^{*}$ & $-1.744^{* * *}$ & -0.762 & -0.420 & $-1.396^{* *}$ \\
\hline Terr/POP & 0.097 & $0.194^{*}$ & 0.088 & 0.109 & 0.032 & -0.932 \\
\hline Multiple bases & $-0.666^{* *}$ & $-0.795^{* * *}$ & -0.438 & $-0.744^{* *}$ & -0.125 & 0.230 \\
\hline Group compet. & -0.022 & $0.054^{*}$ & -0.037 & 0.003 & $0.095^{* *}$ & 0.059 \\
\hline Attack diversity & -0.109 & -3.313 & -1.384 & -1.476 & $3.014^{* * *}$ & -0.527 \\
\hline $\log (G D P / P O P)$ & -0.190 & 0.030 & 0.308 & $-0.483^{*}$ & 0.088 & $0.654^{* *}$ \\
\hline $\log (P O P)$ & 0.082 & $-0.215^{*}$ & $-0.297^{* *}$ & 0.182 & -0.279 & $-0.466^{* *}$ \\
\hline Gov. spending & 3.885 & -3.795 & 1.592 & $5.529^{* *}$ & -2.945 & -1.375 \\
\hline Polity & -0.023 & -0.001 & -0.015 & -0.002 & -0.020 & $-0.053^{*}$ \\
\hline Ethnic frac. & $1.783^{* *}$ & 0.669 & -0.556 & 1.181 & $2.517^{*}$ & -1.311 \\
\hline East As. \& Pa. & 0.295 & -0.030 & 0.634 & 0.119 & -13.072 & 1.046 \\
\hline Eur. \& Cen. As. & -0.340 & 0.610 & $0.932^{* *}$ & -0.401 & 0.854 & $1.121^{*}$ \\
\hline Lat. Am. \& Car. & 0.510 & -0.349 & $1.534^{* * *}$ & 0.586 & -0.378 & $1.913^{* * *}$ \\
\hline North America & $0.877^{*}$ & -1.093 & 0.032 & $0.949^{*}$ & -1.667 & -0.047 \\
\hline South Asia & -1.080 & -0.825 & $1.341^{*}$ & $-2.118^{* *}$ & -0.750 & $2.279^{* *}$ \\
\hline sub-Sah. Africa & -0.380 & 0.090 & $1.763^{* * *}$ & -0.379 & -0.788 & $2.664^{* * *}$ \\
\hline $\log ($ elevation $)$ & $-0.853^{* * *}$ & $0.497^{*}$ & 0.096 & $-0.639^{* * *}$ & -0.292 & 0.244 \\
\hline Tropics & $-1.670^{* * *}$ & 0.181 & -0.300 & $-1.964^{* * *}$ & -0.268 & 0.722 \\
\hline Landlocked & 0.663 & 0.673 & $1.413^{* * *}$ & 0.630 & $1.199 *$ & 0.746 \\
\hline$N$ & & 5576 & & & 5036 & \\
\hline
\end{tabular}

Notes: Significance levels: ${ }^{* * *}$ is $<0.01,{ }^{* *}$ is $<0.05$, and ${ }^{*}$ is $<0.10$. Standard errors, constant, and time variables are suppressed. ERCSR denotes Empire, Regime change, or Social Revolution. Model 1 uses piecewise constant specification (dummy variables for 1970-1979, 1980-1989, 1990-1999, and 2000-2007) and Model 2 uses lagged value of Terr/POP, Group compet., Attack diversity, $\log (G D P / P O P), \log (P O P)$, and Gov. spending

Phillips used a different sample of terrorist groups and a different sample period. These differences pose a challenge for us identifying the state sponsorship status for all of our sample terrorist groups. Therefore, we are understandably cautious about interpreting the findings with respect to our state sponsorship variable. Nevertheless, our results are generally robust to the inclusion of this variable (available upon request). The sign of the state sponsorship coefficient is negative, consistent with the results in Phillips (2013).

Next, we divide our sample into two subsamples: terrorist groups that began before and after the start of 1990. This allows us to investigate the era of the leftist and nationalist/separatist terrorists separately from that of the religious fundamentalist terrorists. This division of the sample period also distinguishes the period of some state sponsorship before 
1990 from the period of much less state sponsorship after the start of 1990 . The dependent variable is a dummy, indicating whether a terrorist group ended in a given year. Unfortunately the restricted sample size does not permit us to investigate the specific manner in which a group ended. ${ }^{9}$ Based on a quadratic duration dependence specification, Table 6 presents the logit regression results.

During its early years, the likelihood of a terrorist group ending in a given year falls with its age; this follows from the statistically significant quadratic time terms in Table 6 and holds for both periods. After an age threshold, every additional year of activity raises the possibility that the group will end in the ensuing period. For both time periods, nationalist terrorist groups are more apt to cease their activities than religious terrorist groups, which supports our theoretical argument. This finding is more statistically significant for the earlier period. The impacts of the other ideological variables are not robust-i.e., left-wing and right-wing terrorist groups are more likely to end relative to religious terrorist groups in the initial period for Model 1, but not for Model 2. For both periods and models, the size of the terrorist group bolsters its survival. There are other noticeable differences in findings for the two periods. Prior to 1990, terrorist groups striving for ERCSR or territorial change are less likely to terminate operations than terrorist groups that seek maintaining the status quo. During this earlier period, having multiple bases of operations, diversifying attacks, and locating in populous countries are conducive to terrorist groups' survival, whereas locating in a landlocked country is not conducive to their survival. The impact of the Latin America \& Caribbean and sub-Saharan Africa dummy variables are positive and statistically significant at the $10 \%$ level, indicating that terrorist groups in these regions are more inclined to end relative to those in the Middle East and North Africa. These results are not statistically significant for terrorist groups that began operations after 1990. After the beginning of 1990, transnational terrorist attacks per capita increase the likelihood that terrorist groups end, presumably because their increased activity exposes them to more risks and enhanced proactive responses from the authorities. Alternatively, increased attacks may motivate the government to allow the terrorist group to join the political process. Competition among terrorist groups significantly reduces the groups' probability of termination, presumably because the authorities' proactive forces are spread thin as they must confront more indigenous terrorist groups. Greater competition among terrorist groups may work against these groups' ability to join the political process, insofar as each group may capture a smaller following. Moreover, with more alternative viewpoints, there may be less need for a terrorist group to splinter, since other options may already exist. The results across the two subsamples generally support our priors.

We also check the results by using lagged values of time-varying variables. For terrorist groups in the initial sample period, the impacts of attack diversity, population, and two regional indicator variables, which are marginally significant in Model 2 in Table 6, are no longer significant. The landlocked variable also becomes statistically insignificant, whereas the polity and elevation variables are now statistically significant. For the pre-1990 period, the other results hold after lagging. For groups started after the beginning of 1990, previously statistically significant variables, except for terrorist group competition, remain statistically significant when we lag time-varying variables. Moreover, left-wing, right-wing, territorial

\footnotetext{
${ }^{9}$ Each sample period now has fewer than 300 groups (see Table 1). Furthermore, our main variables of interest, such as groups' ideologies and goals, have little variation among alternative endings. For example, among right-wing terrorist groups that started after 1990, only a single group splintered and only two groups were defeated militarily.
} 
Table 6 Logit regressions of terrorist groups' endings

\begin{tabular}{|c|c|c|c|c|}
\hline \multirow[t]{2}{*}{ Variable } & \multicolumn{2}{|c|}{ Groups started before 1990} & \multicolumn{2}{|c|}{ Groups started after 1990} \\
\hline & Model 1 & Model 2 & Model 1 & Model 2 \\
\hline $\log ($ size $)$ & $\begin{array}{l}-0.365^{\text {*** }} \\
(0.051)\end{array}$ & $\begin{array}{l}-0.377^{* * *} \\
(0.055)\end{array}$ & $\begin{array}{l}-0.468^{* * *} \\
(0.114)\end{array}$ & $\begin{array}{l}-0.468^{* * *} \\
(0.115)\end{array}$ \\
\hline Left wing & $\begin{array}{l}0.804^{* *} \\
(0.350)\end{array}$ & $\begin{array}{l}0.565 \\
(0.406)\end{array}$ & $\begin{array}{l}0.043 \\
(0.405)\end{array}$ & $\begin{array}{l}0.036 \\
(0.454)\end{array}$ \\
\hline Nationalist & $\begin{array}{l}1.526^{* * *} \\
(0.319)\end{array}$ & $\begin{array}{l}1.236^{* * *} \\
(0.358)\end{array}$ & $\begin{array}{l}0.643^{*} \\
(0.368)\end{array}$ & $\begin{array}{l}0.741^{*} \\
(0.438)\end{array}$ \\
\hline Right wing & $\begin{array}{l}0.999^{* *} \\
(0.457)\end{array}$ & $\begin{array}{l}0.678 \\
(0.503)\end{array}$ & $\begin{array}{l}0.339 \\
(0.531)\end{array}$ & $\begin{array}{l}0.399 \\
(0.574)\end{array}$ \\
\hline ERCSR & $\begin{array}{l}-0.881^{* *} \\
(0.399)\end{array}$ & $\begin{array}{l}-0.847^{* *} \\
(0.410)\end{array}$ & $\begin{array}{l}-0.131 \\
(0.478)\end{array}$ & $\begin{array}{l}-0.152 \\
(0.563)\end{array}$ \\
\hline Policy change & $\begin{array}{l}-0.433 \\
(0.415)\end{array}$ & $\begin{array}{l}-0.295 \\
(0.439)\end{array}$ & $\begin{array}{l}0.028 \\
(0.501)\end{array}$ & $\begin{array}{l}0.123 \\
(0.578)\end{array}$ \\
\hline Territ. change & $\begin{array}{l}-2.221^{* * *} \\
(0.418)\end{array}$ & $\begin{array}{l}-1.992^{* * *} \\
(0.430)\end{array}$ & $\begin{array}{l}-0.289 \\
(0.504)\end{array}$ & $\begin{array}{l}-0.384 \\
(0.568)\end{array}$ \\
\hline Terr/POP & $\begin{array}{l}0.056 \\
(0.053)\end{array}$ & $\begin{array}{l}0.082 \\
(0.052)\end{array}$ & $\begin{array}{l}4.245^{* * *} \\
(1.510)\end{array}$ & $\begin{array}{l}4.171^{\text {*** }} \\
(1.464)\end{array}$ \\
\hline Multiple bases & $\begin{array}{l}-0.502^{* * *} \\
(0.183)\end{array}$ & $\begin{array}{l}-0.755^{* * *} \\
(0.222)\end{array}$ & $\begin{array}{l}-0.134 \\
(0.268)\end{array}$ & $\begin{array}{l}-0.073 \\
(0.314)\end{array}$ \\
\hline Group compet. & $\begin{array}{l}0.001 \\
(0.023)\end{array}$ & $\begin{array}{l}0.039 \\
(0.026)\end{array}$ & $\begin{array}{l}-0.059^{* * *} \\
(0.019)\end{array}$ & $\begin{array}{l}-0.073^{* *} \\
(0.032)\end{array}$ \\
\hline Attack diversity & $\begin{array}{l}-1.709^{* *} \\
(0.792)\end{array}$ & $\begin{array}{l}-1.556^{*} \\
(0.832)\end{array}$ & $\begin{array}{l}-1.914 \\
(3.011)\end{array}$ & $\begin{array}{l}-1.331 \\
(2.906)\end{array}$ \\
\hline $\log (G D P / P O P)$ & $\begin{array}{l}0.109 \\
(0.111)\end{array}$ & $\begin{array}{l}0.101 \\
(0.238)\end{array}$ & $\begin{array}{l}0.022 \\
(0.139)\end{array}$ & $\begin{array}{l}0.076 \\
(0.203)\end{array}$ \\
\hline $\log (P O P)$ & $\begin{array}{l}-0.200^{* * *} \\
(0.070)\end{array}$ & $\begin{array}{l}-0.220^{*} \\
(0.117)\end{array}$ & $\begin{array}{l}0.063 \\
(0.085)\end{array}$ & $\begin{array}{l}0.145 \\
(0.150)\end{array}$ \\
\hline Gov. spending & $\begin{array}{l}1.737 \\
(1.252)\end{array}$ & $\begin{array}{l}1.923 \\
(1.418)\end{array}$ & $\begin{array}{l}2.521 \\
(2.749)\end{array}$ & $\begin{array}{l}1.205 \\
(3.431)\end{array}$ \\
\hline Polity & $\begin{array}{l}0.008 \\
(0.016)\end{array}$ & $\begin{array}{l}-0.003 \\
(0.018)\end{array}$ & $\begin{array}{l}-0.004 \\
(0.027)\end{array}$ & $\begin{array}{l}0.008 \\
(0.035)\end{array}$ \\
\hline Ethnic frac. & $\begin{array}{l}0.870^{* *} \\
(0.393)\end{array}$ & $\begin{array}{l}0.922 \\
(0.655)\end{array}$ & $\begin{array}{l}0.451 \\
(0.618)\end{array}$ & $\begin{array}{l}0.533 \\
(0.911)\end{array}$ \\
\hline East As. \& Pa. & & $\begin{array}{l}0.478 \\
(0.628)\end{array}$ & & $\begin{array}{c}-0.178 \\
(0.743)\end{array}$ \\
\hline Eur. \& Cen. As. & & $\begin{array}{l}0.553 \\
(0.369)\end{array}$ & & $\begin{array}{l}-0.190 \\
(0.464)\end{array}$ \\
\hline Lat. Am. \& Car. & & $\begin{array}{l}0.787^{*} \\
(0.436)\end{array}$ & & $\begin{array}{l}-0.035 \\
(0.693)\end{array}$ \\
\hline North America & & $\begin{array}{l}0.212 \\
(0.457)\end{array}$ & & $\begin{array}{l}-0.397 \\
(0.831)\end{array}$ \\
\hline South Asia & & $\begin{array}{l}-0.229 \\
(0.674)\end{array}$ & & $\begin{array}{l}0.314 \\
(0.643)\end{array}$ \\
\hline sub-Sah. Africa & & $\begin{array}{l}0.918^{*} \\
(0.531)\end{array}$ & & $\begin{array}{l}0.085 \\
(0.776)\end{array}$ \\
\hline $\log ($ elevation $)$ & & $\begin{array}{c}-0.229 \\
(0.175)\end{array}$ & & $\begin{array}{l}0.018 \\
(0.279)\end{array}$ \\
\hline Tropics & & $\begin{array}{c}-0.384 \\
(0.490)\end{array}$ & & $\begin{array}{l}-0.429 \\
(0.537)\end{array}$ \\
\hline
\end{tabular}


Table 6 (Continued)

\begin{tabular}{|c|c|c|c|c|}
\hline \multirow[t]{2}{*}{ Variable } & \multicolumn{2}{|c|}{ Groups started before 1990} & \multicolumn{2}{|c|}{ Groups started after 1990} \\
\hline & Model 1 & Model 2 & Model 1 & Model 2 \\
\hline Landlocked & & $\begin{array}{l}0.900^{* *} \\
(0.352)\end{array}$ & & $\begin{array}{l}0.833 \\
(0.536)\end{array}$ \\
\hline Time & $\begin{array}{l}-0.143^{* * *} \\
(0.026)\end{array}$ & $\begin{array}{l}-0.140^{* * *} \\
(0.027)\end{array}$ & $\begin{array}{l}-0.464^{* * * *} \\
(0.083)\end{array}$ & $\begin{array}{l}-0.451^{* * *} \\
(0.085)\end{array}$ \\
\hline Time squared & $\begin{array}{l}0.004^{* * *} \\
(0.001)\end{array}$ & $\begin{array}{l}0.004^{* * *} \\
(0.001)\end{array}$ & $\begin{array}{l}0.025^{* * *} \\
(0.005)\end{array}$ & $\begin{array}{l}0.024^{* * *} \\
(0.005)\end{array}$ \\
\hline Constant & $\begin{array}{l}0.400 \\
(1.592)\end{array}$ & $\begin{array}{l}1.726 \\
(3.158)\end{array}$ & $\begin{array}{l}-0.357 \\
(2.000)\end{array}$ & $\begin{array}{l}-1.644 \\
(3.113)\end{array}$ \\
\hline$N$ & 4115 & 4115 & 1490 & 1461 \\
\hline
\end{tabular}

Notes: Significance levels: ${ }^{* * *}$ is $<0.01,{ }^{* *}$ is $<0.05$, and ${ }^{*}$ is $<0.10$. Robust standard errors are in parentheses. ERCSR denotes Empire, Regime change, or Social Revolution

change, and polity variables become statistically significant with signs that agree with previous results. In addition, we replace government spending with lagged military expenditure after 1990. This lagged variable is positive and statistically significant, suggesting that military expenditure hastens the demise of terrorist groups. We cannot use military expenditure prior to 1990 because data are not available. We implement a random-effects logit regression to account for unobserved heterogeneity. In general, our results are not sensitive to this change. The exceptions are ERCSR before the start of 1990, and the nationalist and terrorist attack variables after 1990, which are no longer statistically significant. Finally, previous results generally hold if we include the state sponsorship variable. All of these results are available upon request.

\section{Concluding remarks}

This paper extends previous work on terrorist groups' survival to investigate why terrorist groups end in particular ways - defeat by force, splintering from within, and joining the political process or achieving victory. Terrorist groups not succumbing to one of these endings remain active and, thus, pose a risk to the public. Based on multinomial logit regressions of competing risks and a logit regression of terrorist group survival, we estimate the hazard probability for a sample of 586 terrorist groups for 1970-2007 and two subsample periods. These latter periods involve terrorist groups that formed before and after the beginning of 1990.

A number of policy conclusions follow from our results. First, terrorist group size matters for survival; group size has the largest marginal impact for terrorist groups to avoid being defeated by force. For every subsample, group size adds to survival prospects, thereby indicating that it is essential for governments to keep incipient groups from growing. Second, covariates affect the alternative fates of terrorist groups differently. As such, this multinomial analysis can inform policymakers about the likely fates of terrorist groups, so that these policymakers know where to concentrate scarce counterterrorism resources. For example, terrorist groups seeking broad or territorial goals are not likely to join the political process, nor are they apt to end by force or splintering. This then suggests that these terrorist groups 
present an ongoing threat that demands more counterterrorism measures. Relative to religious fundamentalist terrorist groups, nationalist terrorist groups are prone to end by force or joining the political process, which indicates that some of these nationalist groups may give up terrorism through negotiation or the promise of amnesty. Religious fundamentalist terrorist groups represent the greatest current threat and are the most resilient. Thus, more counterterrorism measures must be directed to these terrorist groups. Third, terrorist groups with multiple bases are unlikely to end by force or splintering. This suggests that the authorities must work with their counterparts in other countries to inhibit these multiple bases from forming if the terrorist group is to remain more vulnerable to proactive measures. Fourth, within the base country, terrorist group competition inhibits political solutions, thereby encouraging the authorities to try to create dissent within the terrorist group to promote internal dissolution. Fifth, terrorist groups in the Middle East and North Africa are less likely to join the political process when compared to other regions. The recent geographical shift of terrorist activities to this region after 9/11 has ominous implications for terrorist groups' longevity (Enders and Sandler 2012). As a consequence, more international actions are required to address this development. Sixth, geological and geographical considerations-base-country elevation and tropics-protect terrorist groups from being defeated by force. This suggests either the need for greater proactive measures or else a willingness on the part of the authorities to negotiate a settlement in countries with these characteristics.

Acknowledgements This paper has profited from comments by two anonymous referees and William F. Shughart II. The authors' research was supported by the Vibhooti Shukla Endowment.

Open Access This article is distributed under the terms of the Creative Commons Attribution License which permits any use, distribution, and reproduction in any medium, provided the original author(s) and the source are credited.

\section{References}

Abadie, A. (2006). Poverty, political freedom and the roots of terrorism. The American Economic Review, 96(2), 50-56.

Aksoy, D., \& Carter, D. B. (2014). Electoral institutions and the emergence of terrorist groups. British Journal of Political Science. doi:10.1017/S0007123412000282.

Alesina, A., Devlesschauwer, A., Easterly, W., Kurlat, S., \& Wacziarg, R. (2003). Fractionalization. Journal of Economic Growth, 8(2), 155-194.

Allison, P. D. (1982). Discrete-time methods for the analysis of event histories. Sociological Methodology, 13(1), 61-98.

Asal, V., \& Rethemeyer, R. K. (2008). The nature of the beast: organizational structures and the lethality of terrorist attacks. The Journal of Politics, 70(2), 432-449.

Basuchoudhary, A., \& Shughart, W. F. II (2010). On ethnic conflict and the origins of transnational terrorism. Defence and Peace Economics, 21(1), 65-87.

Berrebi, C., \& Lakdawalla, D. (2007). How does terrorism risk vary across space and time? An analysis based on Israeli experience. Defence and Peace Economics, 18(2), 113-131.

Blomberg, S. B., Engel, R. C., \& Sawyer, R. (2010). On the duration and sustainability of transnational terrorist organizations. The Journal of Conflict Resolution, 54(2), 113-131.

Blomberg, S. B., Gaibulloev, K., \& Sandler, T. (2011). Terrorist group survival: ideology, tactics, and base of operations. Public Choice, 149(3-4), 441-463.

Brandt, P. T., \& Sandler, T. (2009). Hostage taking: understanding terrorism event dynamics. Journal of Policy Modeling, 31(5), 758-778.

Brathwaite, R. (2013). The electoral terrorist: terror groups and democratic participation. Terrorism and Political Violence, 25(1), 53-74.

Carter, D. B. (2012). A blessing or a curse? State support for terrorist groups. International Organization, $66(1), 129-151$. 
Cronin, A. K. (2006). How al-Qaida ends: the decline and demise of terrorist groups. International Security, 31(1), 7-48.

Daxecker, U. E., \& Hess, M. L. (2013). Repression hurts: coercive government responses and the demise of terrorist campaigns. British Journal of Political Science, 43(3), 559-577.

Enders, W., \& Sandler, T. (1993). The effectiveness of anti-terrorism policies: a vector-autoregressionintervention analysis. American Political Science Review, 87(4), 829-844.

Enders, W., \& Sandler, T. (1999). Transnational terrorism in the post-cold war era. International Studies Quarterly, 43(2), 145-167.

Enders, W., \& Sandler, T. (2012). The political economy of terrorism (2nd ed.). New York: Cambridge University Press.

Gaibulloev, K., \& Sandler, T. (2013). Determinants of the demise of terrorist organizations. Southern Economic Journal, 79(4), 774-792.

Gallup, J. L., Mellinger, A. D., \& Sachs, J. D. (1999a). Geography datasets. Boston: Center for International Development, Harvard University.

Gallup, J. L., Sachs, J. D., \& Mellinger, A. D. (1999b). Geography and economic development. Boston: Center for International Development, Harvard University (CID working paper No. 1).

Gould, E. D., \& Klor, E. F. (2010). Does terrorism work? The Quarterly Journal of Economics, 125(4), 1459-1510.

Heston, A., Summers, R., \& Aten, B. (2011). Penn world table version 7.0. Philadelphia: Center for International Comparisons of Production, Income and Prices, University of Pennsylvania.

Hoffman, B. (2006). Inside terrorism, revised and expanded edition. New York: Columbia University Press.

Horowitz, M. (2010). Nonstate actors and the diffusion of innovations: the case of suicide terrorism. International Organization, 64(1), 33-64.

Jenkins, S. P. (1995). Easy estimation methods for discrete-time duration models. Oxford Bulletin of Economics and Statistics, 57(1), 129-138.

Jones, S. G., \& Libicki, M. C. (2008). How terrorist groups end: lessons for countering al Qa'ida (Monograph MG-741-1). Santa Monica: RAND.

Kilberg, J. (2012). A basic model explaining terrorist group organizational structure. Studies in Conflict \& Terrorism, 35(11), 810-830.

Landes, W. M. (1978). An economic study of US aircraft hijackings, 1961-1976. The Journal of Law \& Economics, 21(1), 1-31.

Li, Q. (2005). Does democracy promote transnational terrorist incidents? The Journal of Conflict Resolution, 49(2), 278-297.

Long, J. S. (2012). Regression models for nominal and ordinal outcomes. http://www.indiana.edu/ jslsoc/ files_research/cdanor/Long\%20-\%20Nominal\%20Ordinal\%20Regression\%20Models\%20-\%20201205-29.pdf. Accessed 1 May 2013.

Marshall, M. G., \& Jaggers, K. (2009). Polity IV dataset version 2007 and dataset users' manual. Fairfax: Center for Systemic Peace and the Center for Global Policy, George Mason University. http://www.systemicpeace.org. Accessed 1 July 2009.

National Consortium for the Study of Terrorism and Responses to Terrorism (2009). Global terrorism database. College Park: University of Maryland (GTD) (CD-ROM).

Phillips, B. J. (2013). Terrorist group cooperation and longevity. International Studies Quarterly. doi:10.1111/isqu.12073.

Piazza, J. A. (2008). A supply-side view of suicide terrorism: a cross-national study. The Journal of Politics, $70(1), 28-39$.

RAND (2012). RAND database of worldwide terrorism incidents. http://www.rand.org/nsrd/projects/ terrorism-incidents.html. Accessed 3 August 2012.

Rapoport, D. C. (2004). Modern terror: the four waves. In A. K. Cronin \& J. M. Ludes (Eds.), Attacking terrorism: elements of a grand strategy (pp. 46-73). Washington: Georgetown University Press.

Train, K. E. (2009). Discrete choice methods with simulation (2nd ed.). Cambridge: Cambridge University Press.

Wilkinson, P. (1986). Terrorism and the liberal state (revised edition). London: Macmillan.

World Bank (2010). World development indicators (WDI). http://www.worldbank.org. Accessed 28 November 2010 . 